
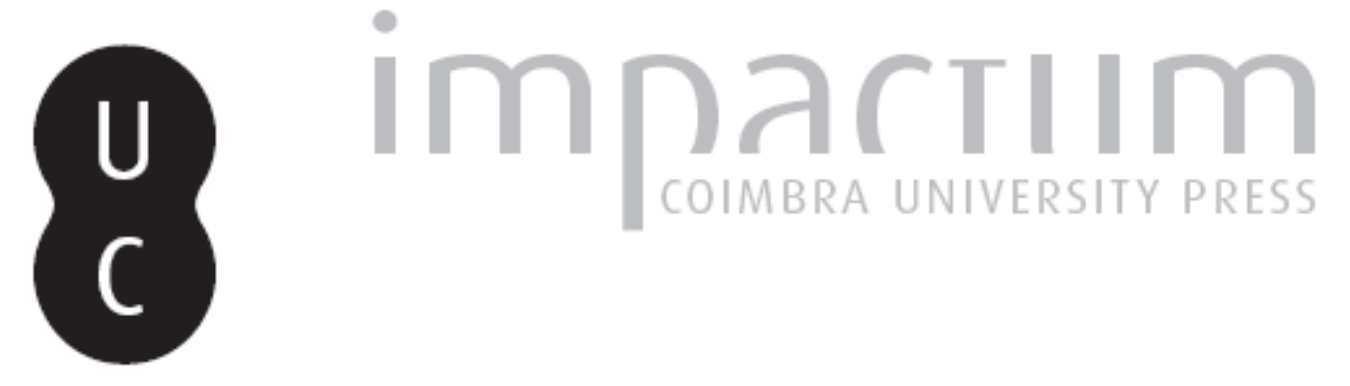

\title{
Ribeiro Sanches e a questão dos judeus
}

Autor(es): $\quad$ Santos, Maria Helena Carvalho dos

Publicado por: Imprensa da Universidade de Coimbra

URL persistente:

URl:http://hdl.handle.net/10316.2/43862

DOI:

DOI:https://doi.org/10.14195/2183-8925_4-1_6

Accessed : $\quad$ 26-Apr-2023 12:52:43

A navegação consulta e descarregamento dos títulos inseridos nas Bibliotecas Digitais UC Digitalis, UC Pombalina e UC Impactum, pressupõem a aceitação plena e sem reservas dos Termos e Condições de Uso destas Bibliotecas Digitais, disponíveis em https://digitalis.uc.pt/pt-pt/termos.

Conforme exposto nos referidos Termos e Condições de Uso, o descarregamento de títulos de acesso restrito requer uma licença válida de autorização devendo o utilizador aceder ao(s) documento(s) a partir de um endereço de IP da instituição detentora da supramencionada licença.

Ao utilizador é apenas permitido o descarregamento para uso pessoal, pelo que o emprego do(s) título(s) descarregado(s) para outro fim, designadamente comercial, carece de autorização do respetivo autor ou editor da obra.

Na medida em que todas as obras da UC Digitalis se encontram protegidas pelo Código do Direito de Autor e Direitos Conexos e demais legislação aplicável, toda a cópia, parcial ou total, deste documento, nos casos em que é legalmente admitida, deverá conter ou fazer-se acompanhar por este aviso.

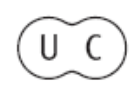




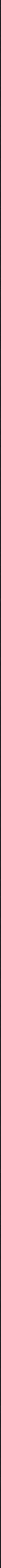


MARIA HELENA CARVALHo dos SANTOS*

\title{
RIBEIRO SANCHES E A QUESTÃO DOS JUDEUS
}

1. Parece fácil, em 1750 , verificar «o miserável estado do reino" denunciado por $D$. Luís da Cunha quase um século depois do apelo de Vieira ( ${ }^{1}$ ). De 1650 a 1750 o país sobrevivera nadando em ouro e afundando-se em pobreza. Tinha-se

\begin{abstract}
* Faculdade de Ciências Sociais e Humanas da Universidade Nova de Lisboa.

Nota - Ao transcrever-se do Journal de Ribeiro Sanches, certamente o seu manuscrito mais pessoal, as Reflexões e demais consideraçjes sobre a questão dos judeus e a legislação pombalina tendente à extinção da distinção entre cristãos-novos e cristãos-velhos, procuramos ser rigorosamente fiéis ao pensamento e à escrita do autor, embora actualizanđo algumas furmas caídas em desuso e que, facilitando a leitura, em nada al:eram o sentido da frase ou a intenção do escritor.
\end{abstract}

Assim, permitimo-nos:

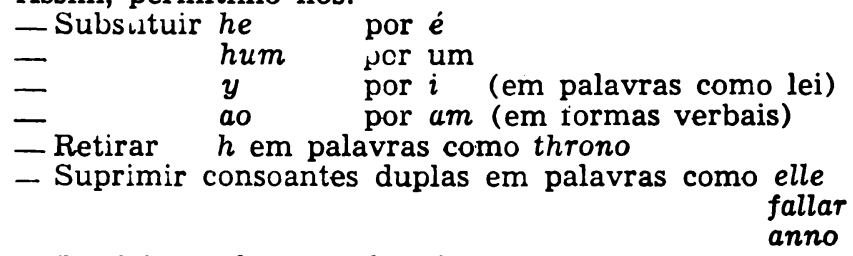

- Desdobrar algumas abreviaturas

- Transcrever éguas onde estava egoas

Tratando-se, embora, de um Diário com rasuras e emendas e não de um texto acabado para publicação, não corrigimos o que quer que fosse no sentido de explicitar o sentido da frase. O leitor poderá aperceber-se de toda a riqueza de pensamento e simplicidade de expressão característica de Ribeiro Sanches.

(1) P.'António Vieira, Obras Escolhidas, prefácio e notas de António Sérgio e Hernâni Cidade, vol. IV, Livraria Sá da Costa, Lisboa. Maria Helena Carvalho dos Santos, Os judeus portugueses no século XVII - as ideias económicas em Vieira, in Revista Altitude, ano II, 2." série, n. 4 , Guarda, Dezembro, 1981, pp. 49 a 95. 
pretendido a impossibilidade de conseguir uma sociedade estática, amparada nas muletas da Inquisição, no ouro do Brasil, nos escravos da Guiné, na imobilidade da propriedade, no ensino escolástico, na aristocracia ineficaz, nas instituições esmoleres.

0 terramoto pombalino vem abalar os alicerces desta sociedade, abrindo os caboucos de uma nova ordem que tardará, no entanto, a afirmar-se. As reformas tendentes a esta mudança estrutural foram levadas a efeito pela legislação pombalina que se inspirou mais nas sugestões dos estrangeirados do que nas reivindicações de uma burguesia nascente $\mathrm{e}$ apenas balbuciante. Pombal tentou testar a validade (entenda-se necessidade) das reformas, através do inquérito $\left.{ }^{2}{ }^{2}\right)$ dirjgido aos párocos em 1758, antes de as implementar, continuando a solicitar expressa ou indirectamente sugestões aos intelectuais portugueses. E-lhe necessária uma radiografia do reino e uma base social de apoio para impor o seu programa de governo.

O absolutismo esclarecido português encontrava-se na teoria e na prática, ignorando todas as suas contradições que, de resto, não lhe eram apontadas pela intelligentzia, transformada no seu melhor suporte.

$\mathrm{Na}$ concepção do absolutismo esclarecido, Pombal deve seguir dois caminhos: impor a soberania régia e civil, submetendo-lhe o poder espiritual e temporal da Igreja e impor meios de desenvolvimento económico. Estes dois problemas interligam-se na questão dos judeus que justificava a existência da Inquisição, mas que prejudicou o desenvolvimento natural do capitalismo pela perseguição movida principalmente ao sector produtivo e negociante da população.

Em 1735 Ribeiro Sanches tinha levantado de novo o problema e esclarecera a "Origem da denominação de cristão velho e cristão novo no reino de Portugal» $\left({ }^{s}\right)$. $\mathrm{O}$ manuscrito tornara-se conhecido e fora recopiado pelos meados do sécu-

(2) As respostas ao inquérito pombalino constituem o Diccionario Geographico de Portugal ou collecção das respostas autographas dos parochos das freguesias do reino, sobre os quesitos que lhes foram enviados pelos respectivos prelados diocesanos, dimanando tudo da auctoridade central, no reinado de D. José $11^{\circ}$ (1758). Esta coleç̧ão é constituída por 43 volumes. Vide nosso artigo em colaboração com Almerinda Teixeira, $A$ radiografia do reino ou o inquérito aos párocos (1758), in Portugal-Hoje, 28 de Abril de 1982.

(') A. N. Ribeiro Sanches, Christãos Novos e Christãos Velhos em Portugal, manuscrito inédito agora publicado com introdução de Raúl Rêgo, Lisboa, 1956. 
lo XVIII, embora Sanches esconda o seu nome e assine Philopater $\left({ }^{4}\right)$.

Entre um conceito de tolerância e uma razão de estado parecem reunidas as condições para resolver definitivamente (?) a questão dos judeus.

2. Todos os estudiosos de António Nunes Ribeiro Sanches têm referido o seu Journal $\left({ }^{5}\right)$, usando-o parcelarmente como fonte. Também nós nos permitimos ir ali encontrar o espírito vivo do estudioso que em notas de agenda foi fixando o seu pensamento. O Journal, tão referido, corresponde, na verdade, a uma Agenda, a um Diário, onde sucessivamente ficam registadas, pouco mais do que em apontamento, as suas preocupações de ordem vária e a sequência da sua vida quotidiana, repartida entre os doentes e as consultas e receituário, os livros, o contacto com amigos russos ou portugueses, as contas, o dinheiro, as despesas domésticas, as reflexões filosóficas ou o apontar de uma ou outra anedota política ou de espírito crítico em relação à sociedade que o rodeava. Fiel aos amigos, persistente nas queixas, requerimentos e pretensões, revela-se-nos um homem comedido, subserviente, acomodado, respeitador da lei e do rei. Por certo que estes seus apontamentos deixam muito que ler nas entrelinhas, mas parece indiscutivel que é um homem para quem várias pátrias não substituem o lugar da sua. E o homem que não se encontra bem em nenhum campo religioso. E um homem para quem a profissão da medicina conduzia a uma prática empírica que não o satisfaz. E um homem que assume a intensidade dramática do intelectual do séc. XVIII, independente no espírito, mas dependente na aceitação da sua produção.

No Journal regista e transcreve, muitas vezes em pormenor, legislação portuguesa ou estrangeira, notas sobre livros ou conhecimentos recentes, que lhe servirão de apoio para emitir opiniões ou elaborar estudos (encomendados ou não).

Quase diariamente regista as suas relações com Portugal através de comerciantes, embaixadores ou directamente para Lisboa. Pelo fim da vida revela a preocupação de manter em ordem o testamento e de orientar o destino da sua biblioteca $\left(^{\circ}\right)$. Também não é difícil detectar toda a sua teimosia

(4) Idem, p. XIII.

(') António Ribeiro Sanches, Journal (1768-1782), manuscrito, na Bibliothèque de la Faculté de Médicine, Paris, cota Ms. 2015.

$\left(^{\circ}\right)$ Sobre as negociaçóes de Ribeiro Sanches a propósito do destino a dar à sua Biblioteca preparamos um trabalho a apresentar no Colóquio Internacional «Pombal Revisitado - alguns aspectos do pombalismo», a realizar em Lisboa e Coimbra em Dezembro de 1982. 


\section{O Marquês de Pombal}

em conseguir o pagamento dos atrasados em relação à tença real que lhe fora concedida, mas que não recebeu entre 1761 e 1769.

A Agenda de Ribeiro Sanches é escrita em português, castelhano, francês, inglês, latim e em uma ou outra página fixa caracteres russos. Embora Sanches use as várias línguas ao correr do pensamento, num hábito mental de vários anos, sem nenhumas preocupações estilísticas ou literárias, não podemos deixar de referir esta escrita como uma certa forma de receio de incomunicabilidade perante um meio que não é o seu. Talvez o faça inconscientemente, apenas na preocupação rápida de fixar as suas tarefas e os seus pensamentos que desenvolveria mais tarde. Assim, um texto iniciado em português pode continuar em outra língua e retomar o português:

«10 de Marco 1769:

"Le Pape Clement XIII est mort le 2 Fevrier 1769. Mort de chagrin, ex cure, sollicitudine, angore que, os Embaixadores de França, de Espanha e de Nápoles lhes representaram que tinham ordem de suas cortes de pedir a S. Santidade que dissolvesse totalmente a Ordem dos Jesuítas. O Papa pediu tempo para dar a resposta; passaram-se três dias, no fim deste parecia em saúde, jantou, ceou, foi meter-se na cama, parece que dormiu, acham-no morto com escuma sanguinolenta na boca. No cadáver tudo se achou são e somente o coração alguma cousa dilatado. Cor aneurismaticum.

«Tanto pode hua paixão da alma!

"Carta que recebi de Mr. le Dr. Payva ( $\left.{ }^{7}\right)$ datada em Roma a 20 de Fevereiro 1769» $\left(^{8}\right)$.

3. Raúl Rêgo, ao divulgar em 1956 o manuscrito «Origem da denominação de cristão velho e cristão novo no reino de Portugal», chamava a atenção para o Journal $\left({ }^{\ominus}\right)$ e para as $R e$ -

(') O Dr. Payva, médico em Roma, é um dos amigos com quem Sanches mantém frequente correspondência e que refere várias vezes no Journal a propósito de troca de informações no campo científico. Em 19 de Janeiro de 1775 escreve sobre o tratamento da epilepsia e diz: «Meu Primo Payva me comunicou o referido na sua carta datada em Roma a 2 de Janeiro de 1775».

${ }^{8}$ ) As negociaçōes entre os Embaixadores e o Vaticano, sobre a questão dos jesuítas, arrastaram-se através dos pontificados de Benedito XIV, Clemente XIII e Clemente XIV. E de 23 de Julho de 1773 o breve «Dominus Redemptor» que extinguiu a Companhia de Jesus.

(') Ob. cit., p. VIII. 
flexões, nele contidas, a propósito da lei pombalina que suprimiu a distinção entre cristãos novos e cristãos velhos $\left({ }^{10}\right)$. Posso agora socorrer-me do Journal de Sanches ( ${ }^{11}$ ) e seguir aí o seu pensamento sobre a grave questão dos judeus, que ele defende como coisa sua e que sente como a injustiça da discriminação.

Não temos provas que nos façam concluir que Ribeiro Sanches fosse um "católico sincero". Admitimos, mesmo, que essas provas serão difíceis de conseguir e apenas nos arrastariam para uma polémica inconcludente. $O$ que encontramos nos seus textos é uma afirmação expressa do seu afastamento formal de qualquer igreja, o que ele próprio acentua quando admite que "pensa como deísta» $\left.{ }^{12}\right)$. Na carta de 1735 a Valadares $\left({ }^{18}\right)$ Sanches escreve que se confessou, mas que não comungou; afirma-se cristão católico romano e arrependido da vida passada, referindo-se ao seu tempo de judeu, em Inglaterra, mas confirma que poderá usar os bons ofícios dos judeus de Londres para manter correspondência com os familiares, no caso de o pretender. Considera os abusos dos judeus, que rejeita, mas constata que em todo o lado passa por judeu inglês.

Quando discute problemas religosos fá-lo na dicotomia judeus-católicos e refere, como que em lapsus linguae que em Bordéus convive com uma família descendente de Solis, que tinha sido queimado vivo em Lisboa num auto de fé. Admite ter estado convencido que a fé judaica era a única verdadeira. Mesmo arrependido de se ter feito circuncisar, o que ele pensa, às vezes, é que seguindo a Bíblia se poderia salvar. Tinha

${ }^{(10)}$ Carta de lei, Constituição Geral e Edicto Perpectuo, de 25 de Maio de 1773. B. N., R., Pomb., 649, lol. 45 a 53 . Sobre este problema deve referir-se outra legislação pombalina: os Alvarás de 2 de Maio de 1768 e 5 de Outubro de 1768; e o de 24 de Janeiro de 1771, embora seja difícil isolar este problema já que ele se inscreve numa problemática mais vasta, contemplada por legislação não específica, como a que se destina, por exemplo, a regulamentar casamentos ou testamentos ou criação de morgadios ou, ainda, a que se refere ao comércio.

(11) Por facilidades concedidas pela Professora Doutora Graça Almeida Rodrigues foi-nos possível consultar e obter cópia do Journal de Ribeiro Sanches (de 11 de Novembro de 1768 a 12 de Dezembro de 1782). Vide supra nota 5.

( $\left.{ }^{12}\right)$ Carta a Manuel Pacheco de Sampaio Valadares, de 15 de Julho de 1735, existente na Biblioteca Pública de Évora. Vide David Willemse, António Nunes Ribeiro Sanches _Elêve de Boerhaave et son importance pour la Russie, Leiden, 1966, pp. 4 a 8. Sanches escrevia: «Por vezes... eu pensava como deísta».

( $\left.{ }^{13}\right)$ Idem. 
36 anos quando assim escrevia. Estaria, por essa época, tão preocupado com a salvação da alma? Ou pretendia encontrar um caminho terrestre que lhe permitisse uma vida estável, sem sobressaltos, sem riscos desnecessários? A verdade é que de 1735 existem dois textos interessantes: a carta que ele dirige ao seu amigo Valadares, de Portugal, e que poderia interceder a seu favor, e o libelo contra o estilo da Inquisição, revelando o seu compromisso na luta pela extinção da distinção entre cristãos novos e cristãos velhos.

Em toda esta matéria o que me impressiona é a necessidade de se confessar, numa atitude de má consciência, mas principalmente numa posição de dependência. Ele toma permanentemente a posição de súbdito, mas de súbdito que precisa de agradar, calculando as possibilidades de êxito ou pelo menos de bom acolhimento para as suas confissões ou para os seus votos e cumprimentos, como fica expresso nos rascunhos da correspondência, no Journal, pela sua exagerada preocupação de corresponder a um tipo de etiqueta que não lhe está na natureza e que o obriga a rasurar e corrigir uma escrita espontânea.

Se podemos admitir que em 1735 desencadeia a questão dos judeus, ele hesita toda a vida entre ser abertamente judeu ou abertamente cristão. Willemse, no seu interessante e útil estudo, não considera importante essa indefinição e aceita a terceira posição, a de Cristão Novo que, afinal, quanto a mim, é a que Sanches rejeita totalmente. Esse é o labéu. Sanches pretende dizê-lo ao rei, mas hesita, mais uma vez, e é ele que nos explica porquê:

\section{"Journal}

\&22 Juin 1773

«Sobre o escrever os agradecimentos pela lei a favor dos XX.NN. Cada um em particular:

"Que esta piedosa lei é digna do maior agradecimento, é evidente: Se os XX.NN. actuais estivessem separados dos mais súbditos, que fossem governados por outras leis civis ou políticas decre. tadas por S. M. esta era a sua obrigação de irem em corpo, os mais notáveis, ou por escrito ou em pessoa, agradecer a honra de entrar no Estado civil e eclesiástico. Mas os XX.NN. estão conhecidos súbditos no Estado, e julgados nos seus tribunais sem diferença dos XX.V.

«O ser X.V. não é honra, nem dignidade. $O$ carniceiro, o porteiro, o apontador das éguas, são XX.VV. e são vils [sic]. Igualarem-se por esta lei 
os XX.NN. aos Velhos não é mais que restitui-los à primeira liberdade que tinham até o ano 1548 a 50, quando começaram as Inquirições. Isto é a restituição do seu estado antigo, mas de nenhum modo, honra ou dignidade nova.

«O agradecimento é devido pela restituição do estado antigo que tinham os XX. Novos e que actualmente possuem por esta lei os que vivem: digo os que vivem, se não descenderem de Pais e Avós penitenciados. Meus Avós e Pais foram penitenciados logo eu não gozo ainda totalmente da restituição do estado antigo de meus antepassados ${ }^{\left({ }^{14}\right)}$; logo parece afectação mais do que verdadeiro agradecimento todo aquele que eu patentear postrado aos pés do trono, porque neste agradecimento não deve entrar (isto no caso que eu desde esta hora pudesse estar hábil para entrar no Estado Eclesiástico, Dignidades, ou exercitar cargos honoríficos, o que dita lei coarcta) a mínima menção do Ministério, como Autor da lei; poderá tomar-se a má parte por que Ele não deve ser mais do que o executor das leis que saiem imediatamente do trono de S. M. Fidelíssima.

«Estes são os motivos porque hesitaria muito escrever carta de agradecimento ao Sr. M. do P.. Além disso é bem difícil determinar como Ele to maria este submisso agradecimento, sendo causas as seguintes: se agradeço directamente o soberano como Autor total (o que deve ser) da lei, sem falar do Ministério, quem sabe se este levará a mal o meu silêncio (por estas razões dubito quid agendum). Se agradeço ao Ministério, ainda que seja mui indirectamente, quem sabe se S. M. F. tomará este proceder, apesar de toda a submissão à Magestade, regular e do seu real animon.

4. Ribeiro Sanches mantinha-se atento à política internacional e à legislação portuguesa, muito especialmente no que dizia respeito à questão dos judeus que não defende apenos no domínio dos princípios, mas também como causa própria.

Em 11 de Julho de 1769 transcreve para o seu Journal a «lei sobre a Inquisição» de 20 de Maio de 1769 . A 12 e a 14

(') Note-se como Ribeiro Sanches considera a lei insuficiente. Aqui se poderá encontrar a razão do seu exílio sem regresso. 


\section{O Marquês de Pombal}

regista algumas notas sobre assuntos diversos. E a $17 \mathrm{de} \mathrm{Ju}$ lho, depois de meditar sobre a questão, que toma apontamentos para um

«Modelo de carta para Roma e para Portugal. "Que algumas famílias portuguesas que vivem em França e Itália na religião cristã, mas conforme o antigo costume português reputadas, tidas e havidas por XX.NN. tendo notícia do Alvará de S.M.F. se persuadem que o estilo da Inquisição, o seu modo de processar fica mudado e que querem ir morar na sua pátria debaixo do domínio do amado e clementíssimo soberano $\left({ }^{15}\right)$.

"Querem saber $10^{\circ}-$ Em cada cidade cabeça de comarca Tribunal de Inquisição se os Reitores Seculares são os Juizes e os Inquisidores no foro interno. O ofício destes se reduz a julgar se a culpa é ou não heresia. E de absolver de heresia. $O$ processo deve ser feito pelos seculares, sem juramento de segredo, declarados os nomes das testemunhas confrontadas no tempo no lugar, no crime e nome dos circunstantes.

«2 Que não haia confiscacão de bens. Que não haja actos $[\mathrm{sic}]$ de fé. Oue se não proceda a prisão do réu sem prévia sentença. se merecelı ou não ser preso. Que a nrisão dos réus seculares ou regulares seja feita pelos ministros de justica real.

«3 Que nenhum processo nem acto se faca sem a assistência e presenca dos assistentes, seculares, para impedirem que os inquisidores formem o processo pelo Directorio e só conforme as leis e uso da Relacão e mais Tribunais seculares do reino, como nos Algarves».

Ao apontar estas questões, Sanches demonstra uma preocupação de rigor e de investigação, copiando para o Diário a Bula do Papa Inocêncio XI, de 22 de Agosto de 1681, a que faz a seguinte introdução:

\footnotetext{
${ }^{\left({ }^{15}\right)}$ A frase havia sido escrita do seguinte modo: «Debaixo do domínio de um tão clemente soberano» que se encontra rasurado, acrescentando as expressões: amado e clementíssimo.
} 
«Esta Bula foi dada no fim do Processo que os XX.NN. de Portugal intentaram em Roma contra a Inquisição de Portugal reinando o Infante Dom Pedro, como Regedor do Reino. 0 Arcebispo de Lisboa Dom Luís de Sousa, Embaixador a Roma para defender a causa da Inquisição fez que terminasse por esta Bula o Processo e que jamais se pôs em execução pela Inquisição de Lisboa».

Ao transcrever a Bula, regista algumas chamadas de atenção, na margem da Agenda, que nos deixam entender as suas próprias preocupações, dúvidas e incontida raiva de impotência, como, por exemplo, quando pergunta:

«Há coisa mais torpe assinada por um papa?» ou quando considera:

«Latim bárbaro saído de Roma! Este latim foi escrito por algum Rábula português canonista»,

ou, em dúvida, escreve:

«E necessário ver o original para se persuadir que isto está bem copiado",

tais os problemas que a Bula de 1681 lhe suscita em 1769 .

E resume, considerando que apenas dos primeiros 4 parágrafos "o estilo [da] frase é feito pela Corte de Roma, bom latim, sentido, ordem, gravidade». Do parágrafo 5 ao 25 , diz que a Bula "foi feita por algum canonista português ignorante da língua latina e que foi criado no proceder das Inquisições de Portugal». Porém, considera que o "resto é palavrório da Corte de Roma em bom latim", para concluir: "O que tudo é uma picardia, falsidade, ignorância, subornação, ódio, tanto do Arcebispo Dom Luís de Sousa como da Corte de Roma». Analisa pormenorizadamente a Bula para aí encontrar fundamentação para a abordagem do problema e escreve:

"Vejo no princípio desta Bula no original os primeiros 4 parágrafos que a Inquisição de Portugal não queria mandar a Roma cinco processos dos réus para os examinar e julgar a Corte de Roma. Se os Cristãos Novos apelantes contra a Inquisição alegavam falso ou verdadeiro. Que o Papa interdisse 
- Inquisidor Geral. O Arcebispo Dom Luís de Sousa Embaixador em Roma mandou vir somente dois que apresentou ao Papa (nas suas cartas li que os pediu de Portugal aqueles mais a propósito e que ele os comporia para apresentá-los). Ele foi o Embaixador e Arcebispo que formou a Inquisição desde o ano 1681 até este ano 1769 » ${ }^{\left({ }^{10}\right)}$.

A questão dos judeus vive de tal forma com Ribeiro Sanches que não deixa de registar o que pode ter sido um fugaz pensamento motivado por uma cena do quotidiano, mas que, ao referi-la, tem para nós quase o valor da obsessão. Trata-se de uma nota no Journal de 31 de Maio de 1771 :

«Abusos que se introduzem pela superstição. «Na Lei Judaica os Milagres todos serviam para dar terror e destruir os mortais. Na Cristã os Milagres de Cristo todos foram para ajudar, conservar e favorecer a raça humana, porque só a dos porcos foi mal tratada. E verdade que se duvida porque em Palestina não havia destes animais.

$\propto \mathrm{E}$ por tanto quanto vão os Judeus a queimar no Acto [sic] de fé, na procissão que faz aquele Santo Tribunal da Inquisição, levam o crucifixo diante com a cara virada para os que hão-de ser queimados ou relaxados naquele dia.

«Na procissão de Corpus Cristi [de] 30 de Maio 1771 em Paris, vi que levavam o Santíssimo Sacramento em charola debaixo do Pálio; a procissão era composta além dos clérigos, de frades capuchos. Um deles levava um crucifixo levantado com a cara para o Santíssimo Sacramento e ao lado iam seis tambores tocando e a música militar de pífaros.

«Então me veio ao pensamento que tratavam aqui a Religião com pompa militar e que levando

(w) a partir de 1769 que Ribeiro Sanches volta a receber a pensão ou tença que lhe fora atribuída em 1759, mas suspensa em 1761. A data de 1769 pode corresponder a um reatamento de boas relações entre Sanches e a Corte de Lisboa e talvez corresponda, também, a novas encomendas, como parece sugerir a nota do Journal de 8 de Agosto: « Carta do Sr. Dom Vicente de Sousa Coutinho para que receba a pensão de Setembro em diante com o custo da Impressão to Methodo». Trata-se do Metodo para aprender e estudar a medicina, illustrado com os apontamentos para estabelecerse huma universidade real na qual deviam aprender-se as sciencias humanas de que necessita o estado civil e político, Paris, 1763. 
assim o crucifixo, que parecia a um português, que iam a queimar aquele Santo Mistério. - Tal é a força da Educação!».

Ao ter conhecimento da Carta de Lei de 25 de Maio de 1773, Ribeiro Sanches escreve em 22 de Junho de 1773:

«Reflexões sobre a lei decretada por S. Magestade Fidelissima José Primeiro, em Maio 1773. "Extinguindo o nome distintivo de X.N. e X.V. e que os ditos XX.NN. sejam em tudo iguais aos XX.VV. capazes de gozarem e exercitar cargos, dignidades honrosas.

«Esta piedosissima lei é fundada nas máximas e constante prática da Igreja Católica Romana Universal, como nas mesmas da Primeira Igreja, conforme os Concilios Gerais e a prática constante do Império de Alemanha, França, Castela, Itália e Portugal até o ano 1536 quando a Inquisição se estabeleceu em Portugal a rogos del Rei Dom João o III ao Papa......... ( $\left.{ }^{17}\right)$ e principalmente depois que se introduziram no mesmo reino as Inquisições de Sangue à imitação do Cabido de Toledo no ano 1548 e ordenado pelo Breve do Papa........ com o título de Puritate ( ${ }^{\mathbf{1 8}}$ ).

"Desde aquele tempo se introduziu naqueles dois reinos a diferença de X.N. e de X.V. O Directório das Inquisições destes reinos e prática constante de tirar Inquirições de sangue para entrar no Estado Eclesiástico, entrar nas Ordens Militares, servir o Estado nos cargos da Judicatura, no Estado Militar ou das Frotas, ser Notário Público, etc. aumentou prodigiosamente o número dos XX.NN.. $\mathrm{E}$ vivia mais de a metade das duas Naçōes deshonrada com o nome difamante de X.N. se milhares destes não fugissem para terras estrangeiras católicas romanas ou protestantes.

(") O Papa Clemente VII, pela Bula de 17 de Dezembro de 1531, nomeia Fr. Diogo da Silva «comissário da sé apostólica e inquisidor de Portugal e seus domínios», sendo confirmado pelo Breve de 13 de Janeiro de 1532. As negociações arrastam-se e a Bula de 16 de Julho de 1547 já é do Papa Paulo III. Vide A. Herculano, História da Origem e Estabelecimento da Inquisição, t. I e II. 1 Julho 1773.

${ }^{(8)}$ O Breve de Puritate é de Sisto V. Cfr. Sanches, Journal, 
«Não duvido que mui poucos serão do parecer que acabo de manifestar. Me arguirão de modo seguinte:

"Introduziram-se as Inquisições em todos os Domínios da Itália, exceptuando no reino de Nápoles, desde o décimo tertio século. Estas Inquisições se governavam e governam ainda pelo Directório que a Corte de Roma ordenou; continuaram no seu exercício até os nossos dias e principalmente nos Estados do Papa, e não vemos que pelas ditas Inquisições e seu Directório, apesar de muitos culpados e sentenciados por eles, que nestes Estados se conhecesse até agora a distinção entre os mesmos XX de nome X.N. e de X.V. senão evidente, que as Inquisições em Castela e Portugal não foram a causa do infamante nome de $X$. Novo.

«Mas é engano manifesto daqueles que têm por máxima que para conservar a pureza de Fé, que é necessário que a Igreja e o Estado sejam Intolerantes. Que estes prelados ou Ministros pensem se - Directório das Inquisições de Roma e do Reino de Itália é em tudo semelhante ao Directório das Inquisições de Castela e de Portugal. Que reparem se na Alemanha católica, no reino da Sardenha e no resto dos Estados da Itália, se ouviu jamais que um cristão baptizado e observante da lei de Cristo foi jamais obrigado a tirar Inquirições de sangue para entrar no Estado Eclesiástico, entrar nas Ordens Militares ou exercer Cargos honrosos Civis e Militares. Apesar que nos reinos onde nunca foram conhecidas as Inquirições, muitos Judeus, Maometanos, abjuraram a lei de seus pais e que se converteram à de Cristo, nunca naquelas terras se ouviu jamais que os seus descendentes ficassem infamados do nome de Cristão Novo. Em Castela e Portugal desde o ano 1548 quando principiou o uso (abuso dirá o verdadeiro cristão) de tirar Inquirições, se perpectuou a infâmia da sua ascendência. Porque tendo os XX.VV. horror para se misturarem por casamentos com os novamente convertidos, vieram a ser notados, desprezados e aborrecidos, já se vê por causa alguma mais efectiva do que aquela do uso introduzido de tirar Inquirições.

"Mas esta não foi a principal causa da separação dos cristãos com os nomes X.V. e X.N. nos reinos das duas Espanhas. A principal causa destes 
perturbadores nomes e do seu aumento, foi o Directório das Inquisições estabelecidas neles desde o ano 1482. Reinando os Reis Católicos, e sem embargo que foi aprovado pelos Papas, veremos quanto difere daqueles de Roma, de Veneza e do resto da Itália, ordenados pelos mesmos Papas. Aqui havia bastante matéria para admirar-se da vontade, da inconstância e da avareza da Corte de Roma. Como estas qualidades estão dadas a conhecer por muitos autores católicos romanos e protestantes não fatigaremos a quem quiser ler um dia estas reflexões.

\section{\&DIVERSIDADE}

«Dos Directórios das Inquisições de Roma, comparadas com o Directório das Inquisições de Castela e de Portugal.

«Eu pudera aqui traduzir o Directório de Roma que tenho manuscrito, como aquele da Inquisição de Veneza, escrito e comentado por Fra Paulo, ano 1639, com este título sem lugar de impressão "Discorso dell' Origine forma Leggi ed uso dell' uficio dell' Inquisitione nella cita e Dominio de Venetia de S. Paulo dell' ordine de servi». Pudera aqui copiar aquela Bula de Inocencio XI que serve de Directório às Inquisições de Portugal desde o ano 1681. Mas seria molesto e enfadonho. Para abreviar esta matéria tão ingrata, e para representar quanta destruição e desolação pudera causar este Directório ao reino de Portugal, abolindo-se nela pela lei acima a diferença entre X.N. e X.V. e que izualando todos os súbditos cristãos vivam como vivem os nascidos italianos, franceses e alemães. Porei aqui como se praticam estes Directórios em Roma e Portugal, para que o leitor se aperceba visivelmente da diferença que há entre eles e quão pernicioso seria a Portugal o Directório das suas Inquisições, observando-se a lei decretada em Maio 1773.

«O Delactor nas Inquisições de Portugal serve de testemunha para proceder a prisão do acusa[do]. "Na Inquisição de Roma o Delactor neste Tribunal não serve de testemunha. Posto que sejam três ou cinco delactores do mesmo homem acusado. Sobre a deposição dos delactores a resolução que toma aquele tribunal é fazer uma inquirição oculta 
da vida religiosa do acusado, se escreveu, falou, con. versou contra o que crê a Igreja católica, se observa os seus mandamentos, ouvir missa, jejuar, desobrigar-se no tempo da quaresma. Esta inquirição feita por pessoas dignas de fé, depõem o que lhes foi imposto no mesmo tribunal, servem de testemunhas contra o acusado para condená-lo ou absolvê-lo. "O dito Tribunal julga então conforme a inquirição se deve proceder a prisão nos seus cárceres ou se reputar-se por falsa a acusação. Deste modo se vê a grande diferença que há entre o Directório de Roma, Veneza e entre o Directório da Inquisição de Portugal. Nesta toda a pessoa que delacta ou a um familiar do S.t $\mathrm{t}^{\circ}$ Ofício ou a um dos seus comissários, ou na Mesa do mesmo tribunal serve ali de testemunha. Duas testemunhas destas ou três são suficientes para mandar prender nos seus cárceres o acusado. Estes Tribunais portugueses não mandar [sic] inquirir por pessoas fidedignas se o acusado incorreu no crime de heresia por acções exteriores, se vive ou não cristamente, como costuma inquirir-se e informar-se a Inquisição de Roma e de Veneza.

«Nas Inquisições de Portugal todo o homem, mulher, solteiro ou solteira menor depois da idade de 14 a 15 anos, acusados por delactores, são presos por este tribunal. Ele tem por verdade irrefragável que toda a denunciação é verdadeira, que todo o delactor é inteligente nas matérias da fé, verdadeiro cristão, sem paixão alguma de ódio nem vingança. Proceder diferente das Inquisições de Itália. Nestas jamais se ouviu, que por maravilha, que mulher ou rapariga menor fosse presa por aquele tribunal. Em Portugal é tão notório que se prendam mulheres viúvas, casadas, solteiras menores por crimes de feitiçaria, de judaísmo, de entusiasmo e de superstição, que saiem relaxadas desde a idade de 16 e 17 anos e justiçadas por sentença da Relação, que não havia execução mais ordinária, que se liam nas listas dos Actos [sic]. Não quero aqui ponderar a violação do direito natural da decência, do tirano e cruel costume e de irem lá pela alta noite os familiares daquele tribunal a prender e a tirar da cama a mulher casada entre os braços do marido, e a filha donzela em semelhantes horas de entre os braços da mãe aflita, levados alta noite por um fami- 
liar, ficarem reclusas no lugar que lhes parecia, sempre à sua ordem, conduzi-las por oito ou dez dias por caminhos de 40 e de 50 léguas entregá-las ao tribunal de quem depende este horroroso executor de semelhantes ordens. Deixo à consideração dos que pensam como cristãos piedosos se não é vexação, calamidade e crueldade semelhantes prisões no sexo modesto, casto e honrado.

"Semelhante proceder nunca se viu em Itália, nem as suas Inquisições chegaram a tais excessos. "Aquele réu que se vê preso nas Inquisições de Itália está firmemente certo que foi sentenciado juridicamente a prisão naquele tribunal e que pelas suas acções exteriores se fez culpado. Neste caso determina a confessar a sua acusação que lhe declaram: se insiste na negativa fica reduzido até confessar. Aqui não declaram os nomes das testemunhas que inquiriram as suas acções contrárias ou omissas à lei em que foi baptizado. Este réu sabe que se acusar verdadeira ou falsamente os seus cúmplices que não será absolvido enquanto não confessar a suas culpas e mostrar o seu arrependimento. Sabe que ficará recluso por toda a vida se insistir na negativa. Se é tão mentecapto que quer suster os erros de que foi acusado sabe que morrerá sepultado vivo porque aqueles tribunais não costumam relaxar nem os negativos nem os profitentes ao braço secular, como costumam as Inquisições de Portugal, e costumavam as de Castela até o ano 1717 no seu último Acto [sic] de Fé na Plaza Mayor de Madrid.

"Se este mesmo réu acusar os seus cúmplices, ele não serve de testemunha, nem outros mais delatores, para determinar a prisão, o delatado ou delatados. Aqueles tribunais de Itália, como já disse, mandam então inquirir e pesquisar por pessoas fidedignas as acções exteriores dos delatados, as suas omissões nas matérias da fé e Santos Sacramentos. Se se acharam culpados, se sentenceia a causa à prisão. Se, pelo contrário, o delatado ficou absoluto [sic] e em santa paz. E deste modo tão naras vezes se observam prisões nestas Inquisições de Roma, e muito menos naquela de Veneza, porque aquelas de Milão e de Florença se aboliram pelos Príncipes reinantes da Casa de Áustria. 
"Vejamos agora como se formavam e julgavam as causas do Santo Ofício em Portugal desde o ano 1681 pela Bula de Inocêncio XI Papa. Declaro que tudo o que disser abaixo nesta matéria que não é com outra intenção que para obviar a destruição da minha amada Pátria, se se conservar ao mesmo tempo o Directório das Inquisições de Portugal e observar a piedosíssima lei decretada em Maio deste ano de 1773 por S. M. Fidelíssima. Declaro que tudo o que disser que o ouvi de homens e de mulheres que saíram confessos e penitenciados por aqueles tribunais portugueses, além do que achei escrito na Bula acima e em alguns manuscritos. E achando todos conformes me persuadi da sua verdade. Qualquer que conhecer o regular modo da Inquisição de Portugal se persuadirá que o crime de judaísmo, do maometismo, da heresia dos calvinistas, etc., de sodomia e de feitiçaria, serão todos processados e sentenciados do mesmo modo e pelas mesmas formas.

«Eu não tratarei mais que do modo que se precessavam os presos, réus acusados de judaísmo, ou fosse X. Velho ou X.N. porque só deste modo de processar estou informado dos mesmos culpados e penitenciados.

«Neste tribunal há duas sortes de testemunhas. A primeira é a de sangue, a segunda é a de sangue totalmente diferente. A testemunha de sangue quanto mais próximo é o grau de sanguinidade é mais válida para proceder a prisão, do que a testemunha que é de sangue em grau apartado ou separado. Duas ou três testemunhas de sangue bastam para ser preso o acusado. Mas necessitam-se mais testemunhas, vg, quatro (e já três foram bastantes para prender 60 famílias que habitavam em Beja, XX.NN. acusadas por três testemunhas cristãs velhas) ou cinco testemunhas cristãs velhas serão bastantes para prender um cristão novo, sendo acusado por elas de judaísmo. Do mesmo modo quatro ou cinco até sete testemunhas $\mathbf{X X}$. novas denunciando e acusando um $X$. Velho o poderão fazer prender. Estas testemunhas não são forçosas nem válidas para obrigar aquele tribunal a relaxar ao braço secular.

«Também por três modos são presos e acusados os XX.NN.. O primeiro por denunciação de 
duas ou três testemunhas XX. Velhas ou XX. No vas, perante um familiar, um Comissário ou perante o mesmo tribunal. Estas denúncias são raras. E só acidentalmente vem a ser nocivas, como se dirá abaixo.

«A segunda denunciação ou acusação é daqueles presos XX. Novos enquanto se lhes faz o seu processo, que acusam outros XX.NN. parentes chegados, ou em grau mais distante, e que esta acusação é bastante para determinar a prender estes denunciados com duas ou três testemunhas conforme a proximidade do sangue, vg, Pai, filho, mulher e marido, irmãos, primos irmãos, etc.

"A terceira sorte de denunciação dos XX.NN. dos dois sexos, viúvas, casadas e solteiras que vão acusar-se à Inquisição ou a um Comissário ou a um Familiar, que tem culpas que confessar no S.t. Ofí- $^{\circ}$ cio e que dá parte ao Santo Tribunal, ao que chamam apresentar-se ou apresentados.

"Sucede que subitamente em uma vila ou cidade foi preso um X.N. ou dois pela Inquisição, que se lhes põem barras às portas, que deitam desta casa na rua mulher e filhos e que todos aaueles bens ficam em sequestro por ordem do S. $t^{\circ}$ Ofício. Que fazem e que pensem os mais cristãos NN. a quem estas prisões vieram à sua notícia ou que os presos sejam ou não sejam seus parentes? $O$ que fazem é ordinariamente apresentar-se diante de um Familiar ou na Inquisição. Este tribunal quando acha a propósito lhes ordena de virem fazer a sua confissão e dar-lhes a absolução, o que executam à risca.

«Vem a Lisboa, a Coimbra e a Évora, presentam-se aos Tribunais da Inquisição que ali existem e são perguntados em mesa dos inquisidores, como todos os presos quando entram na Inquisição, às vezes carregados de ferros (o que sucedeu algumas vezes).

«Estas perguntas consistem: como se chama? onde nasceu? onde foi bautisado ou bautisada? como se chamava seu pai, mãe, avô, avó, o nome dos irmãos que tem? se solteiros, casados? e os filhos que tem? tudo [sic] estas respostas escreve o secretário da Mesa para saber aquele Tribunal a genelogia do réu. 


\section{O Marquês de Pombal}

«1. Perguntam mais pela doutrina cristã.

«2. Depois que confesse os erros que prometeu confessar.

«Em 3. lugar com quem se declarou por palavras, ou acções contra a crença e os preceitos da Santa Madre Igreja. Responde que se acusa crer na lei de Moisés, que não trabalhava no sábado, que não comia carne de porco, etc. Que se declarou unanimamente com fulano ou fulana, de quem é obrigado dizer o nome, onde habita, que parentesco tem com ele ou ela? o seu estado e geneologia, sendo necessário naquele Tribunal, sem embargo de ser de gente escrava.

«E qual foi a causa que este X.N. se foi apresentar, creia ou não creia na lei de Moisés? Foi o medo que tem daquele preso que prenderam seu conhecido, sabendo que lá dentro da Inquisição o denunciará com outros mais presos que estão no mesmo Tribunal seus parentes ou conhecidos. Por este meio e para não ser preso, nem presa, nem perder os seus bens.

«Nesta consideração, este apresentado acusa de judaísmo cinquenta ou 60 pelo menos, seus parentes e com predilecção aqueles que estão reclusos na Inquisição. Com verdade ou mentira, isso não é do caso. $O$ ponto é acusar e principalmente os que estão presos.

«Mas o que tem destruido milhares de famílias desde o ano 1547 até 50 que sairam primeiro para Hamburgo, para Holanda, Inglaterra, Africa, França e Itália e que acabaram ainda desterrados em Angola e no Brasil e que morreram queimados vivos profitentes relaxados no braço secular ou negativos de garrote, ou queimados da lei errada em que morriam foi o modo de processar estes tribunais portugueses os presos XX.NN. acusados pelos três modos acima declarados.

«Prende-se um X.N. ou X. Nova, casada ou solteira, menor ou maior, vem a ser reclusa no cárcere. E chamado à Mesa dos Inquisidores pequena ou grande. $\mathbf{O}$ primeiro interrogatório é um tudo semelhante àquele dos apresentados ao mesmo Tribunal que dissemos acima.

«O segundo interrogatório é confessai as vossas culpas. Muitos, falsa ou verdadeiramente dizem que ele é pecador mas que não tem que acusar-se de ter 
abjurado a Religião que professou sempre cristã. Continua a negar e a insistir que está inocente, uma e duas vezes diante daqueles senhores. E chamado pela $3 .^{\mathrm{a}}$ vez ou quarta e persistindo na negativa, vem o Promotor com o libelo que consta, como todos sabem, das acusações contra o réu, impenitente, falso e ficto, pela primeira entrada.

«E diz provará que estando em certo lugar se declarou por palavras de presente, que ele cria na lei de Moisés, que observava o sábado, e que ambos (e às vezes cinco ou seis) convieram e acordaram que esta era a verdadeira lei e que nela viveria e observaria.

«Provará que em certo lugar haverá 10 ou 20 anos se declarou com certa pessoa do seu sangue (ano mais ou menos aqui não se repara; o ponto é dar no vulto) por palavras de judaísmo, etc.

«E a fim vai aumentando os pontos do libelo a proporção das testemunhas que o acusaram ou sejam presos ou apresentados, que vivem fora ainda na sua liberdade.

«E acaba o libelo, que sendo convencido da sua falsidade está sujeito a ser relaxado, seus bens confiscados, etc. e o mandam recolher para o seu cároere.

«Este preso entrando na sua prisão, ou esteja só, ou acompanhado, (que é o estado mais perigoso, porque o companheiro o poderá acusar com novas culpas, o que sucedeu algumas vezes) considera que é necessário confessar ou pelo menos acabar a vida de garrote. Mas a quem declarará ele por cúmplice do seu delito? O libelo lhe nomeia só o número das testemunhas contra si, mas sem declaração dos nomes. Começa a passar pela memória todos conhecimentos que tem dos seus parentes, amigos e conhecidos dos dois sexos. Suspeita que fulano que saiu no Auto de fé, que veio apresentar-se o acusariam como cúmplice do judaísmo. Suspeita que só algum X.N. que não é seu parente, nem seu amigo, seria a causa do perigo onde se vê. Todos estes repõe na memória, bate na grade do cárcere, vem o guarda e o alcaide, pede-lhes Mesa e o levam diante dos seus juizes.

«Assentado, começa a fazer a confissão, isto é, declarar e acusar outras tantas pessoas XX. No vas, como o número daquelas que contou quando 
- Promotor lhe lia o libelo. Bem se pode considerar, que não lhe havendo declarado o nome dos acusadores cúmplices, que falsamente acusou muitas com quem nunca falou.

"O Directório da Inquisição só nesta matéria é coerente: o delator do crime de que acusa algum delinquente, vivendo em liberdade, é reputada neste tribunal por testemunha válida. $O$ que está preso e a quem se faz o processo acusando os seus cúmplices, é também reputado testemunha válida.

"Proceder condenado pelas Inquisições da Itália, onde o delator não serve mais do que averiguar a vida, as acções exteriores, o exercício dos sacramentos da Igreja, se se observam ou não, conforme a Religião de Cristo.

«Sucede que o preso acima depois de confessar, é chamado à mesa daqueles senhores e lhe declaram que não cumpriu ainda a sua confissão. Dão-lhe um letrado. Mas que letrado? Este sem vista dos autos, sem nomear-lhe o nome das testemunhas, sem conhecer a qualidade, a valia das testemunhas que o acusaram, para contraditá-las, tudo - que aconselha o seu suplicante é que confesse, porque aqueles senhores são mui misericordiosos. De tal modo que o preso, ou se determina a começar de novo a acusar todos os que conheceu, adivinha quem te deu, ou amua e se cala. Como a confissão está diminuta, o Directório ordena que sendo testemunha de sangue próxima, singular ou muitas que o réu não quer confessar, que se julgue a tratos ou a ser relaxado, o que se fazia tantas vezes desde que se publicaram as listas dos Autos de fé depois do século XV. E ouvi dizer a um médico e a um letrado em Portugal, homem de juizo, e que sairam penitenciados, que se não fora pela piedade e bondade da maior parte dos inquisidores que todos que entravam culpados na Inquisição sairiam a morrer porque o Directório está feito com tanto ódio e vingança santa, como dizem, que nenhum processado conforme o seu estabelecimento sairia com vida daquele tribunal.

«Para não parecer que o sangue me corre pelas veias, calo o que são os tratos de cordas a homens, mulheres, donzelas, sem outra cobertura que uma 
camisa e umas grandes ceroulas, entre quatro algozes, que tiram as asas das cordas atadas em 8 partes, pernas, coxas e em duas partes nos braços. Calo o trato nos cárceres. Calo outros incidentes vergonhosos, onde os guardas e os alcaides tem toda a falta. Calo outras muitas coisas que mostrariam que dito Tribunal foi inventado pela fúria mais infernal que se mostrou neste mundo. E apelo para a leitura dos processos da Inquisição feitos somente por três anos, em qualquer dos séculos que tem existido em Portugal.

«A vista do referido como bom patriota, como amante da humanidade e como cristão obrigado a amar o seu próximo, digo e declaro e fico persuadido que se S. M. Fidelíssima, que Deus guarde, defenda e projecta, quer e deseja que a sua lei sobre igualar todos os seus subditos no estado de cristão velho, seja para bem, e aumento dos seus povos, vendo e admirando a sua alta clemência e providência, será obrigado mandar abolir, extinguir e queimar diante dos pelourinhos das cidades onde estão sitas as Inquisições, o Directório da Inquisição, e que se acharem contrárias ou contrários ao Directório da Inquisição de Roma fica claro e evidente que são faltas, subreptícias, pretendidas e alcançadas com enganos, ódio, soberba, traição à santa Religião Católica Romana e ao mesmo reino, como se vê claramente pelas cartas em volume in fol. manuscritas do Arcebispo de Lisboa Dom Luís de Sousa, Embaixador em Roma pelos anos 1681, que negociou os negócios do Estado actual das Inquisições de Portugal, o qual manuscrito pelo espólio do Balio de Sousa morto em Paris pelos anos 1760 , pouco mais ou menos, passou a Malta com o resto dos seus livros e móveis. Este manuscrito pertenceu ao Sr. Dom António Alvares da Cunha, Trinchante Mor e Guarda Mor da Torre de Tombo. Paris, 22 de Junho 1773».

Estas reflexões não são um texto definitivo, embora o seu autor as escreva em função de um leitor. Seria um texto a ser retocado e que foi completado logo no dia seguinte. $\mathbf{A}^{2} 23$ de Junho, Ribeiro Sanches transcreve para o seu Journal parte do "Prólogo» da lei e em 1 de Julho tece-lhe os seguintes comen. tários: 
\REFLEXÕES SOBRE O PRELÓQUIO ACIMA

«Observou o Conselho Geral do Santo Ofício que as prisões naquele Tribunal eram raríssimas desde a abertura da Inquisição 1536 até 1567 . Mas que logo que a Bula de Sixto Quinto de Puritate no ano 1567 ou 1568 foi publicada e que a Inquisição começou a processar os presos conforme a tal inovação que milhares se prenderam de ali por diante, sinal certo que o Directório foi mudado e que o modo de processar os presos foi dali por diante mui diferente, além da dita Bula de Puritate.

«Se o Directório desde o princípio fosse o mesmo até o ano 1681 e desse tempo até hoje constituisse - que os delactores a acusadores fossem testemunhas ou estando em liberdade ou apresentando-se, ou dentro da Inquisição, confessando os seus cúmplices, sem vista nem conhecimento do nome das testemunhas, sem podê-las nem contestar nem confrontar, digo que nesse caso havia de haver muitas mais prisōes antes da Bula de Puritate do que houve depois.

«E a razão é: como todos eram tidos por XX. VV. conforme as leis Del Rei Dom Manoel e Del Rei Dom João o III $^{\circ}$, seguia-se que um preso $\mathrm{X}$. Velho naquele tempo havia de confessar as culpas pelas quais foi preso do mesmo modo que se praticou depois da Bula de Puritate. Mas pela deposição do Conselho Geral se vê o contrário. Logo naquele intervalo de 1536 até 1657 processava-se por outro Directório mui diferente daquele pelo qual se processou depois do ano 1567. Este novo Directorio faria a distinção entre X.V. e X.N.. Fez que as testemunhas de sangue fossem forçosas para se mandarem prender os delatados. Fez deste modo que perecessem e acabassem de mil modos os XX.NN., cristãos verdadeiros ou gentes da lei de Moisés. Fez as confiscações. E fez por último que ficassem livres da Inquisição os XX.VV. ainda que fossem acusados de deismo, ateismo, calvinismo, etc. Isto é o que o Conselho Geral fazia bem de publicar para bem do reino e Del Rei».

Devemos referir que é o próprio Diário de Sanches que nos remete para data posterior, ao escrever em nota: «vide abayxo ann. 1775/25 de Janeiro», sem dúvida do seu próprio punho. 
Mais uma vez Sanches está preocupado com a questão dos judeus, só que os seus apontamentos nos poderiam conduzir em erro de datas. $\mathrm{E}$ que no texto indicado de $25 \mathrm{de} \mathrm{Ja}$ neiro de 1775, encontra-se em nota de margem: "vem do ano 1772. Julho deste Journal». Na verdade, vem do ano 1773, como vimos e não podia ser de outro modo, já que os comentários são suscitados pela lei de 25 de Maio desse ano e o escrito "Reflexões» de Ribeiro Sanches está datado por ele próprio. 0 que acontece é que o autor aproveitou parte de duas folhas de papel do Journal de Julho de 1772, apenas escritas de algumas linhas na parte superior, aliás cortadas e sobre assuntos diferentes.

E o próprio Sanches levado em erro ${ }^{19}$ ) quando, procurando folhas atrás, apenas refere a indicação do início da página e que seria mais fácil de identificar. Será de pouca monta este reparo. Ele serve apenas para acentuar que Sanches segue a legislação pombalina e pontualmente a medita e a tem presente no espírito enquanto no seu Journal a mantém actualizada, talvez pretendendo encontrar nela as suas próprias sugestões ou indicações.

Assim, em Janeiro de 1775 volta a preocupar-se com as leis portuguesas sobre este assunto e promulgadas em Dezembro de 1774:

\&LEI DE S. MAGESTADE FIDELISSIMA DE 20 DEZEMBRO 1774.

"Que habilita todos os penitenciados com sanbetino ou confessos a possuir e exercitar cargos honrosos, ficando com a honra e cargos que tenham antes de serem julgados pelo St. Ofício.

"Ordem de S. M. F. mandada pelo Ex. ${ }^{\text {mo }}$ Marquês de Pombal a todos os Corregedores do Rei datada no Palácio Nossa Senhora da Ajuda a 11 de Março 1774.

"Que contém os seguintes motivos e resolução.

«Como pela lei do 25 de Maio de 1773 ficavam habilitados os chamados cristãos NN. a pretender cargos honrosos, começaram estes a querer entrar por Irmãos e Confrades das Misericórdias do Reino, das Irmandades, das confrarias estabelecidas em todas as cidades, vilas e aldeias do reino. Os seus

${ }^{10}$ ) O erro não parece intencional, já que é fácil de detectar. No entanto, poderia corresponder a alguma outra Reflexão ou proposta enviada para Lisboa, em 1772? Nada, no seu Diário, no-lo irǘicá. 
Directórios negaram aos ditos suplicantes a incorporação que pediam. Estes alegavam a seu favor a lei de 25 de Maio 1773 e naturalmente se queixaram na corte da injustiça que lhes faziam de que resultou a ordem acima de S.M.F. que pelos corregedores do reino foi executada, ordenando-lhe que se examinassem por sua ordem todos os Estatutos e regulamentos pelos quais se governavam ditas irmandades, confrarias, misericórdias. E que se neles se achassem a distinção de X.N. ou de X.V. e que fosse por eles defendido aos primeiros de entrar em ditas confrarias e misericórdias, que fossem truncados, borrados, de tal modo que jamais se puder [sic] ler e para ficar abolida toda a memória desta irreligiosa, tirana e abusiva distinção. Mandando meter nas prisões das cabeças das comarcas todos aqueles directores ou governadores de ditas confrarias, misericórdias, etc. que recusassem admitir todos aqueles cristãos bem procedidos, nas ditas irmandades, ou que recusassem borrar os Estatutos respectivos e regulamentos, onde aparecesse a exclusão dos chamados antecedentemente XX.NN. e que depois de estarem presos que os corregedores dariam conta à Secretaria do Estado do Reino, conforme estava determinado pela lei du (sic) 25 de Maio 1773».

E a esta legislação, que em parte encerra a questão, que Ribeiro Sanches faz os últimos comentários que lhe conhecemos sobre o problema da distinção entre Cristãos Velhos e Cristãos Novos e que transcrevemos a seguir.

Este texto foi apresentado por David Willemse, na obra já referida $\left({ }^{20}\right)$, mas traduzido em francês. Para completar a documentação sobre a questão dos judeus pareceu-nos que o devíamos incluir como Sanches o escreveu, no seu Journal:

\footnotetext{
"CONSIDERAÇÕES NASCIDAS DAS LEIS ACIMA PARA O FUTURO

«E certo que o desprezo para o sangue judaico e, por conseguinte, o ódio e o rancor mesmo até à oitava parte deste sangue no mais gentil corpo, ainda que fidalgo, foi a origem e a causa do nome infame, deshonroso, sem termo e sem extensão, de cristão novo. E verdade que pelas leis acima devia
}

(\$) Ob. cit., p. 11. 
ficar este vergonhoso e infame nome, extinto. Mas podem estas leis referidas extinguir da memória e do pensamento as ideias que se adquiriram na primeira idade, ouvindo os pais e mães tratar os descendentes de judeus por infames, traidores a Cristo Nosso Senhor, que o açoutaram, que o fizeram morrer em uma cruz? poderá o menino e o adulto esquecer os sermões que ouviu nas sextas feiras da Paixão: poderá esquecer que foram queimados por arrenegarem a fé de Cristo? Os pais, as mães, os párocos, nos confessionários e os pregadores nos púlpitos publicando e pregando que os judeus e seus descendentes, posto que bautisados, depois de nascer sempre ficavam judeus, porque conservavam naquele sangue puxante uma alma sempre judaica, que os obrigava a arrenegar da fé de Cristo. Logo as leis referidas não poderão jamais abolir o ódio e o desprezo que tem a nação primitiva portuguesa para os XX. Novos. Serão necessários outros meios para convencê-los do seu erro, do que não pretendo agora tratar.

"O que poderá suceder (o que Deus não permita) passados alguns anos ou por morte de S.M.F. (que Deus guarde e conserve por muitos anos) será que o ódio antigo contra os XX.NN. pelas referidas leis se aumentará e que havendo ocasião, livres do temor castizo, todos aqueles que foram castigados com açoutes, exílio, perdas de honra e de ofícios por haverem desobedecido às ditas leis serão e ficarão os mais cruéis e tiranos inimigos do sangue ju. daico que vem ainda e com furor e com raiva entranhável se vingarão com ferro e lama e toda a sorte de tormentos para extinguirem um sangue que aborrecem e aborreceram seus antepassados, sempre com rancor, sempre com ódio, sempre com vingança implantada no interior do coração, consequências forçosas e procedidas da ignorância, do entusiasmo fradesco, da tirania da Corte de Roma, da sua venalidade, do seu proceder contra as leis enfim do SS. Evangelhos.

«Não acusemos os Reis católicos romanos que crêem e aprovam tudo que a Corte de Roma lhes insinuava e ordenava: os seus ministros, bispos, párocos, frades, pregadores, confessores, inculcaram desde a sua meninice, tudo que pode fazer um reino pobre, ignorante, supersticioso, tirano, inimigo da 
humanidade, do bem comum e daquele Amor hoje desconhecido por semelhantes cristãos, que tanto $e$ em tantos lugares recomendam os Evangelhos, inspirados, escritos e pregados por judeus convertidos, é verdade, à lei de Cristo".

5. Estas considerações de Ribeiro Sanches parecem ir ao encontro da necessidade de reformas estruturais, começando pela educação. Percebe-se a sintonia em que ele está com essas medidas pombalinas, embora no texto acima seja visível a sua repugnância por atitudes brutais e de violência. E contra a ignorância que ele está. Se os meninos e os adultos deixassem de ouvir certas considerações abusivas, traduzidas nas frases feitas dos sermões, talvez, diria Sanches, fosse mais fácil entender e aceitar as leis. Nas considerações de Sanches está subjacente a necessidade de formar uma base social de apoio às medidas pombalinas, para lá de uma elite cultural pré-existente. As prisões e as medidas de força revelam que ela não era tão vasta como seria de desejar para implementar uma nova mentalidade. Afinal, quem vai contestar Pombal não são os intelectuais, mas "um reino pobre, ignorante, supersticioso, tirano, inimigo da humanidade».

$\mathrm{Na}$ "continuation du journal» Ribeiro Sanches escreve a 15 de Março de 1777:

«El Rei Dom José Primeiro de Portugal levou Deus para si a vinte e três para 24 de Fevereiro 1777. Seu neto casado com sua filha a Senhora Infanta Dona Mariana [?] Princesa do Brasil foi reconhecida Rainha e seu marido o Infante Dom Pedro Rei. "O Marquês de Pombal despedido, e que entregasse os Papeis a Aires de Sá. Os Irmãos Del Rei que estavam no Buçaco livres e todos os que estavam na Junqueira pela Inconfidência, os Padres do Oratório licença para ensinar, pregar e confessar».

Mais nada. A partir de então as suas preocupações orientam-se para outros campos que têm a ver com o fim da vida. Ribeiro Sanches era da idade do Marquês de Pombal: tinha 78 anos. Os seus destinos, diferentes, encontraram-se em alguns momentos. Agora serão os seus haveres e principalmente a sua biblioteca que passarão a ocupar o centro das suas preocupações, latentes no Journal e que se arrastarão, sem solução, até à sua morte, em 1783, em Paris. 